\title{
Instytucja rozkładania na raty i umarzania należności z tytułu składek na ubezpiecze- nie społeczne rolników
}

\section{Institution of farmers' social security contributions, payment in installments and extinguishment of receivables}

\footnotetext{
Streszczenie

Przymusowość opłacania przez rolników miesięcznych składek jest efektem podlegania ubezpieczeniu społecznemu. Zaprzestanie uregulowania składek we wskazanym przez ustawę terminie płatności lub też zapłacenie w niepełnym wymiarze sprawiają, że wymiar składek jest powiększany o odsetki naliczane za każdy dzień zwłoki. Jednak ustawa o ubezpieczeniu społecznym rolników przewiduje możliwość rozłożenia na raty i umorzenia należności z tytułu składek. Artykuł odnosi się do tego zagadnienia z perspektywy orzecznictwa sądów administracyjnych z ostatnich lat, a także przedstawia to zagadnienie w odniesieniu do praktyki i danych liczbowych.
} 


\section{Summary}

Due to social insurance, paying social security contributions is compulsory for farmers. By ceasing settlement of contributions as due date indicated in the bill or paying partly, the size of contributions is increased by the accrued interest for each day of delay. However, the law on social insurance for farmers, provides the possibility of paying in instalments and remission of contributions. Article refers to this issue from the perspective of the administrative courts judicature of recent years, It also presents this issue with regard to practice and figures.

Kluczowe słowa: składki na ubezpieczenie społeczne rolnika, liczba układów ratalnych, orzecznictwo sądów administracyjnych, uznanie administracyjne, ważny interes zainteresowanego, domownik, możliwości płatnicze.

key words: administrative courts' judicature, administrative recognition, farmers' social security contributions, important interests of concerned party, the householder, the ability to pay.

\section{Wstęp}

Składki na ubezpieczenie społeczne są formą daniny publicznej, o czym stanowi art. 5 ust. 2 pkt 1 ustawy z dnia 27 sierpnia 2009 r. o finansach publicznych. Obowiązek ich ponoszenia na rzecz wyodrębnionych państwowych funduszy celowych wynika z postanowień odrębnych ustaw. 0 możliwości rozkładania na raty i umarzaniu należności stanowi art. 41a ustawy ${ }^{1} \mathrm{z}$ dnia 20 grudnia 1990 r. o ubezpieczeniu społecznym rolników. Z faktu podlegania ubezpieczeniu społecznemu rolników wynika obligatoryjność opłacania przez rolników miesięcznych składek. W przypadku zaniechania ich uregulowania we wskazanym przez ustawę terminie płatności czy też zapłacenie

\footnotetext{
1 Ustawa z dnia 20 grudnia 1990 r. o ubezpieczeniu społecznym rolników, Dz.U. 2016 r., poz. 277, 2043, [dalej:
} 
ich w niepełnym wymiarze, wymiar składek jest powiększany o odsetki naliczane za każdy dzień zwłoki.

Jeżeli rolnik znajduje się $\mathrm{w}$ trudnej sytuacji materialnobytowej $^{2}$, powodującej niemożliwość uregulowania wpłat składek w wyznaczonym przepisami terminie, lub z tytułu nieopłaconych w terminie składek powstało zadłużenie, rolnik może zwrócić się z wnioskiem o zastosowanie ulgi w spłacie do najbliżej placówki terenowej lub oddziału regionalnego Kasy Rolniczego Ubezpieczenia Społecznego, w której podlega ubezpieczeniu.

KRUS może udzielić ulgi w spłacie $\mathrm{w}$ formie: odroczenia terminu płatności bieżącej składki, rozłożenia zadłużenia na raty czy też zmniejszenia wysokości wcześniej udzielonych rat. Na wniosek zainteresowanego decyzję o umorzeniu całości lub części należności z tytułu składek może podjąć Prezes Kasy Rolniczego Ubezpieczenia Społecznego lub upoważniony przez niego pracownik ${ }^{3}$.

\section{Przepisy dotyczące obejmowania ubezpieczeniem społecznym rolników}

O podmiotowym i przedmiotowym zakresie ustawy stanowi art. 1 ustawy o u.s.r. Ustawodawca dla określenia ubezpieczenia społecznego rolników posługuje się w ustawie ogólnym terminem „ubezpieczenie".

Jak wynika z brzmienia powołanego przepisu, ubezpieczenie to obejmuje, na zasadach określonych w ustawie, rolników i pracują-

\footnotetext{
2 http://www.krus.gov.pl/zadania-krus/ubezpieczenie-spoleczne-rolnikow/ulgi-wsplacie-naleznosci-i-umorzenia/, dostęp: 26 stycznia $2017 \mathrm{r}$.

3 A. Jonik, Umorzenie należności $\mathrm{z}$ tytułu składek na ubezpieczenie społeczne rolników w świetle kodeksu postępowania administracyjnego, „Ubezpieczenia w Rolnictwie" 2007, nr 30, s. 33.
} 
cych z nimi domowników, którzy: 1) posiadają obywatelstwo polskie lub 2) przebywają na terytorium Rzeczypospolitej Polskiej na podstawie wizy, zezwolenia na pobyt czasowy, zezwolenia na pobyt stały, zezwolenia na pobyt rezydenta długoterminowego Unii Europejskiej, zgody na pobyt ze względów humanitarnych, zgody na pobyt tolerowany lub w związku z uzyskaniem w Rzeczypospolitej Polskiej statusu uchodźcy lub ochrony uzupełniającej lub 3) są obywatelami państw członkowskich Unii Europejskiej, Konfederacji Szwajcarskiej lub państw członkowskich Europejskiego Porozumienia o Wolnym Handlu (EFTA) - stron umowy o Europejskim Obszarze Gospodarczym.

Ubezpieczenie obejmuje obywateli państw członkowskich Unii Europejskiej i innych wymienionych w art. 1 ust. 1 pkt 3 ustawy o u.s.r., jeżeli przepisy Unii Europejskiej dotyczące stosowania systemów zabezpieczenia społecznego nie stanowią inaczej. W ubezpieczeniu społecznym rolników wyodrębnia się dwa rodzaje ubezpieczeń, są to: ubezpieczenie wypadkowe, chorobowe i macierzyńskie, a także ubezpieczenie emerytalno-rentowe. Zgodnie z brzmieniem art. 3 ustawy o u.s.r., ustawa przewiduje dwie formy objęcia ubezpieczeniem w zależności od przesłanek spełnianych przez osobę zainteresowaną. Jest to tryb obowiązkowy, z mocy ustawy lub dobrowolne objęcie ubezpieczeniem, na wniosek.

\section{Rozkładanie na raty i umarzanie należności z tytułu składek na ubezpieczenie}

0 rozkładaniu na raty i umarzaniu należności stanowi art. 41a ustawy o u.s.r. Ustęp pierwszy przepisu stanowi o możliwości Prezesa Kasy lub upoważnionego przez niego pracownika Kasy, w sytuacjach uzasadnionych ważnym interesem zainteresowanego, na jego wniosek, uwzględniając możliwości płatnicze wnioskodawcy oraz stan finansów funduszów emerytalno-rentowego i składkowego, do: 1) 
odroczenia terminu płatności należności z tytułu składek na ubezpieczenie, rozłożenia ich spłaty na raty lub umorzenia $\mathrm{w}$ całości lub w części; lub 2) umorzenia należności Kasy z tytułu nienależnie pobranych świadczeń w całości lub części.

Prezes Kasy lub upoważniony przez niego pracownik Kasy może także, z urzędu, umorzyć część lub całość należności z tytułu składek, jeśli zaistnieje ich całkowita nieściągalność, która zachodzi, gdy: w wyniku postępowania egzekucyjnego lub na podstawie posiadanych dokumentów stwierdzono, że dłużnik nie posiada źródeł dochodu i majątku, z którego można dochodzić należności, oraz brak jest możliwości przeniesienia odpowiedzialności; lub w sytuacji drugiej, gdy dłużnik zmarł, nie pozostawiając majątku, z którego można by dochodzić należności, i jednocześnie nie ma możliwości przeniesienia odpowiedzialności; lub też w przypadku, gdy kwota należności nie przekracza pięciokrotnej wartości upomnienia w postępowaniu egzekucyjnym; czy też $\mathrm{w}$ sytuacji, gdy jest oczywiste, że w postępowaniu egzekucyjnym dotyczącym należności nie uzyska się kwoty przewyższającej koszty postępowania egzekucyjnego.

Umorzenie składek skutkuje również umorzeniem odsetek za zwłokę w całości lub w takiej części, w jakiej zostały umorzone składki, a także powoduje umorzenie należnych Kasie kosztów upomnienia. Od należności z tytułu składek, których spłatę rozłożono na raty, nie nalicza się odsetek za zwłokę, począwszy od następnego dnia po wpływie wniosku. Jeśli dłużnik nie opłaci w terminie odroczonej składki lub ustalonych przez Kasę rat, kwota niezapłaconych składek staje się wymagalna wraz z odsetkami za zwłokę liczonymi od dnia następującego po dniu, w którym upływa termin płatności wynikający $\mathrm{z}$ art. 40. $\mathrm{W}$ razie dokonywania wpłat na poczet rat, na jakie została rozłożona należność z tytułu składek, wpłatę zalicza się na poczet składek o najwcześniejszym terminie płatności i należnych od nich odsetek za zwłokę. 


\section{Podstawowe pojęcia}

Pojęcie strony postępowania, zainteresowanego zostały zakreślone przez Wojewódzki Sąd Administracyjny w Warszawie, w wyroku 4 z dnia 20 grudnia 2007 r. Za stronę postępowania w sprawie umorzenia należności z tytułu składek na ubezpieczenie społeczne rolników można uznać osobę zobowiązana do uiszczania tych składek, a ściśle rzecz biorąc osobę, która mając obowiązek uiszczania składek $\mathrm{z}$ obowiązku tego nie wywiązała się $\mathrm{w}$ terminie i w związku z tym doszło do powstania zaległości z tego tytułu oraz odsetek od tych zaległości.

Tak również należy rozumieć użyte w art. 41a ustawy z dnia 20 grudnia 1990 r. o ubezpieczeniu społecznym rolników, pojęcie "zainteresowanego", który jest uprawniony do złożenia wniosku o odroczenie terminu płatności należności z tytułu składek na ubezpieczenie, rozłożenie spłaty tych należności na raty bądź ich umorzenie w całości lub w części.

Definicje pojęć znajdują się w art. 6 ustawy o u.s.r. Rolnik to pełnoletnia osoba fizyczna, zamieszkująca i prowadząca na terytorium Rzeczypospolitej Polskiej, osobiście i na własny rachunek, działalność rolniczą w pozostającym w jej posiadaniu gospodarstwie rolnym, w tym również w ramach grupy producentów rolnych, a także osobę, która przeznaczyła grunty prowadzonego przez siebie gospodarstwa rolnego do zalesienia. Domownik natomiast jest osobą bliską rolnikowi, po ukończeniu 16 roku życia, pozostająca z rolnikiem we wspólnym gospodarstwie domowym lub zamieszkująca na terenie jego gospodarstwa rolnego albo w bliskim sąsiedztwie, stale pracująca $\mathrm{w}$ tym gospodarstwie rolnym i niezwiązana $\mathrm{z}$ rolnikiem stosunkiem pracy.

\footnotetext{
${ }^{4}$ Wyrok Wojewódzkiego Sądu Administracyjnego siedziba w Warszawie z dnia 20 grudnia 2007 r., sygn. akt V SA/Wa 1841/07, Legalis 273013.
} 


\section{Uznanie osoby za domownika}

Zgodnie z wyrokiem ${ }^{5}$ Naczelnego Sądu Administracyjnego z dnia 14 stycznia 2015 r. dla wyjaśnienia pojęcia domownika istotne są okoliczności wyczerpujące przesłanki określone w art. 2 pkt 2 ustawy z dnia 14 grudnia 1982 r. o ubezpieczeniu społecznym rolników oraz członków ich rodzin oraz w art. 6 pkt 2 ustawy z dnia 20 grudnia 1990 r. o ubezpieczeniu społecznym rolników. W każdej sprawie, okoliczności należy ustalić indywidualnie, tj. związek z rodzajem działalności rolniczej prowadzonej w gospodarstwie, zakresem prac wykonywanych zarówno przez rolnika, jak i przez jego rodzinę, a także prac wykonywanych przez osobę zainteresowaną oraz częstotliwością wykonywania tych prac. Nieodzowne jest również ustalenie innej aktywności zainteresowanego w tym okresie, a także oddziaływanie tej aktywności na możliwość świadczenia stałej pracy w gospodarstwie rolnym. Powołując się na przykład podany w wyroku przez sąd, w odniesieniu do zainteresowanych będących uczniami należałoby określić typ szkoły do której uczęszczali, rozmiar zajęć szkolnych i niezbędny wymiar pracy własnej po zajęciach szkolnych, a także odległość szkoły od miejsca zamieszkania uczniów.

Jak zważył Wojewódzki Sąd Administracyjny z siedzibą w Warszawie $\mathrm{w}$ wyroku $^{6} \mathrm{z}$ dnia 7 listopada 2012 r., w rozumieniu ustawy o u.s.r., charakter pracy domownika w gospodarstwie rolnym nie może być utożsamiony $\mathrm{z}$ charakterem pracy rolnika $\mathrm{w}$ takim gospodarstwie. Domownik bowiem, w przeciwieństwie do rolnika, nie prowadzi zawodowej działalności rolniczej na własny rachunek, lecz jedynie pomaga w prowadzeniu takiej działalności, co sprawia, że nie musi on pracować $w$ takim samym wymiarze godzinowym. $W$ opinii sądu, takie rozumienie charakteru pracy domownika wskazane zostało już przez sam fakt rozróżnienia przez ustawodawcę w art. 6 pkt 1

\footnotetext{
${ }^{5}$ Wyrok NSA z dnia 14 stycznia 2015 r., Legalis 1218313.

${ }^{6}$ Wyrok WSA z dnia 7 listopada 2012 r., sygn. akt II SA/Wa 1418/12, Legalis 830124.
} 
i 2 ustawy o ubezpieczeniu społecznym rolników definicji rolnika i domownika.

Jak pisze Marek Rotkiewicz w wyjaśnieniu praktycznym7, ewentualne opłacanie składek na KRUS powinno zostać uznane za dowód uznania danej osoby za domownika. Nie może to stanowić jednak dowodu warunkującego uznanie danej osoby za domownika. Jak podkreśla WSA w Warszawie ${ }^{8} \mathrm{w}$ wyroku z dnia 8 czerwca $2010 \mathrm{r}$., błędna jest interpretacja przepisu art. 6 pkt 2 lit. c) ustawy o u.s.r., polegająca na przyjęciu, że brak ubezpieczenia skarżącego wyklucza uznanie go za domownika w rozumieniu powyższej ustawy i w efekcie uniemożliwia zastosowanie do niego dobrodziejstwa art. 1 ust. 1 pkt. 3 ustawy $^{9} \mathrm{z}$ dnia 20 grudnia 1990 r. o wliczaniu okresów pracy w indywidualnym gospodarstwie rolnym do pracowniczego stażu pracy.

\section{Ważny interes zainteresowanego}

Pojęcie „ważny interes zainteresowanego" było niejednokrotnie analizowane przez sądy administracyjne. Jest to zwrot niedookreślony, zawierający dwa odmienne elementy: opis faktu - „interes zainteresowanego", wymagający stwierdzenia, a także element ocenny „ważny”, który wymaga oszacowania wagi stwierdzonego faktu ${ }^{10}$. Przepis art. 41a ustawy o u.s.r. w ust. 1 odnosi się do „ważnego interesu zainteresowanego", dlatego na potrzeby artykułu, nieodzownym jest wytłumaczenie tego pojęcia. Odnosząc się do opinii wyrażonej

\footnotetext{
7 M. Rotkiewicz, Praca $w$ gospodarstwie rolnym w stażu pracy, wyjaśnienie praktyczne, 5 lipca 2016 r., Legalis.

8 Wyrok z dnia 8 czerwca 2010 r., sygn. akt II SA/Wa 180/10.

9 Ustawa o wliczaniu okresów pracy w indywidualnym gospodarstwie rolnym do pracowniczego stażu pracy z dnia 20 lipca 1990 r., Dz.U. Nr 54, poz. 310.

10 Z. Ofiarski, Przesłanki pozytywne umorzenia należności z tytułu składek na ubezpieczenie społeczne, Prawo Budżetowe Państwa i Samorządu, 2(2)/2014, ISSN 2300 - 9853, s. 24.
} 
w wyroku11 Wojewódzkiego Sądu Administracyjnego z siedzibą w Kielcach z dnia 16 lipca 2014 r.: „Nie wystarczy wskazać źródło utrzymania, lecz konieczne jest ustalenie relacji pomiędzy wysokością należności a dochodem, pomniejszonym o wydatki konieczne dla egzystencji konkretnego zobowiązanego i jego rodziny pozostającej z nim we wspólnym gospodarstwie domowym. [...] Ważny interes w umorzeniu składek ze względu na trudną sytuację ubezpieczonego istnieje wtedy, gdy pomiędzy obowiązkiem zapłaty należności i jego sytuacją materialną istnieje związek tego rodzaju, że wykonanie obowiązku zapłaty składek mogłoby spowodować niemożność zaspokojenia przez zobowiązanego i jego bliskich podstawnych potrzeb życiowych".

W wyroku ${ }^{12}$ Wojewódzkiego Sądu Administracyjnego z siedzibą w Rzeszowie z dnia 25 lipca 2013 r. została wyrażona opinia, iż niemożność zapłacenia przez ubezpieczonego składki, rozumiana jako całkowity brak środków na jej realizację lub też jako brak środków na zapłatę bez uszczuplenia podstawowych potrzeb życiowych, przemawia za przyjęciem wystąpienia ważnego interesu ubezpieczonego, co powinno w konsekwencji spowodować brak wydania decyzji odmownej. Podobne stanowisko przedstawił Wojewódzki Sąd Administracyjny z siedzibą w Lublinie $\mathrm{w}$ wyroku ${ }^{13} \mathrm{z}$ dnia 4 grudnia $2012 \mathrm{r}$. Należy jednak mieć na uwadze, że ryzyko ponoszenia strat niejako wpisane jest w prowadzenie każdej działalności, a tym bardziej rolniczej, np. ze względu na zależność produkcji od warunków atmosferycznych. Straty tego rodzaju nie mogą stanowić nadzwyczajnych okoliczności, których stwierdzenie prowadziłoby do rozłożenia na-

\footnotetext{
11 Sygn. akt I SA/Ke 365/14, Legalis 1059413.

12 Sygn. akt I SA/Rz 381/13, Legalis 801674.

13 Sygn. akt III SA/Lu 588/12, Legalis 582745.
} 
leżności na raty. $\mathrm{W}$ takim bowiem razie stosowanie ulg przybrałoby formę powszechną, a nie wyjątkową ${ }^{14}$.

Przesłanka z art. 41a ust. 1 ustawy o ubezpieczeniu społecznym rolników, tj. "uzasadniony ważny interes zainteresowanego", jest pojęciem nieostrym i niesprecyzowanym przez ustawodawcę. W związku z tym, treść tego pojęcia jest bardzo pojemna, co oznacza że może dotyczyć również powoływania się przez stronę na błąd organu, a powinna być oceniana na tle konkretnych okoliczności danej sprawy ${ }^{15}$.

\section{Pojęcie "możliwości płatniczych wnioskodawcy" jako przesłanki umorzeniowej}

Możliwości płatnicze wnioskodawcy określonych w art. 41a ust. 1 ustawy o u.s.r., nie powinno rozumieć się tylko jako możliwość zaspokojenia wierzytelności z tytułu nieopłaconych składek (tj. ściągalność wierzytelności) według stanowiska Wojewódzkiego Sądu Administracyjnego w Warszawie, wyrażonego w wyroku ${ }^{16} \mathrm{z}$ dnia 26 lipca $2011 \mathrm{r}$.

Nie w każdej sytuacji, gdy wnioskodawca jest w stanie zaspokoić wierzytelności z majątku, należy domniemywać istnienie po jego stronie możliwości płatniczych. Tego typu wnioskowanie byłoby oparte na uproszczeniu, które nie znajduje oparcia w przepisach prawa.

\footnotetext{
14 Wyrok Wojewódzkiego Sądu Administracyjnego siedziba w Rzeszowie z dnia 10 maja 2012 r., sygn. akt I SA/Rz 247/12, Legalis 519390.

15 Wyrok Wojewódzkiego Sądu Administracyjnego siedziba we Wrocławiu z dnia 9 września 2010 r., sygn. akt III SA/Wr 877/09, Legalis 374907.

16 Sygn. akt V SA/Wa 925/11, Legalis 374888.
} 
W opinii WSA w Warszawie, potwierdzone jest to poprzez wyniki wykładni systemowej, gdyż "nieściągalność" składek stanowić może podstawę umorzenia należności na podstawie art. 41a ust. 2 ustawy o ubezpieczeniu społecznym rolników, a nie ust. 1 tego przepisu. Identyczne stanowisko przedstawił Wojewódzki Sąd Administracyjny w Lublinie w wyroku17 $\mathrm{z}$ dnia 22 listopada $2011 \mathrm{r}$.

\section{Decyzja w sprawie umarzania należności - uznanie administracyjne}

Decyzje w sprawie umarzania należności z tytułu składek są wydawane $\mathrm{w}$ ramach tzw. uznania administracyjnego. W związku z tym, nawet zaistnienie okoliczności opisanych w hipotezach stosownych przepisów nie obliguje organu do wydania decyzji korzystnej dla zobowiązanego, czyli umarzającej należności ${ }^{18}$.

W celu zbadania uznania administracyjnego, należy odróżnić uznanie od dowolności oceny. Autorzy Komentarza ${ }^{19}$ do Kodeksu Postępowania Administracyjnego, uważają, iż z punktu widzenia uznaniowości organu administracji publicznej kluczowe jest to, aby ocena dokonana przez ten organ nie była oceną dowolną ${ }^{20}$. Ponadto, uzasadnieniu decyzji uznaniowej stawia się szczególne wymagania, ponieważ z jego treści musi wynikać, że decyzja ta nie cechuje się dowolnością ${ }^{21}$. Należy odnieść się także do stosunku wadliwości uzasadnienia do zasad ogólnych Kodeksu Postępowania Administracyjnego. Jak można przeczytać w komentarzu ${ }^{22}$ pod red. red. prof. zw. dr hab. Romana Hausera oraz prof. zw. dr hab. Marka Wierzbowskiego:

\footnotetext{
17 Sygn. akt III SA/Lu 600/11, Legalis 408772.

18 Wyrok WSA w Lublinie z dnia 16 października 2012 r., sygn. akt III SA/Lu 391/12, Legalis 550760.

${ }^{19}$ Kodeks postępowania administracyjnego. Komentarz, red. prof. zw. dr hab. Roman Hauser, red. prof. zw. dr hab. Marek Wierzbowski, wyd. 3, C.H.BECK, Warszawa 2017. ${ }^{20}$ wyrok WSA w Gliwicach z 6 lutego 2009 r., III SA/GL 1421/08, Legalis.

${ }^{21}$ wyr. NSA 8.9.1998 r., IV SA 893/97, niepubl.

22 Kodeks postępowania administracyjnego. Komentarz, red. prof. zw. dr hab. Roman Hauser, red. prof. zw. dr hab. Marek Wierzbowski, wyd. 3, C.H.BECK, Warszawa 2017.
} 
„Wadliwe uzasadnienie decyzji uznaniowej, które nie pozwala na jednoznaczne stwierdzenie, że rozstrzygnięcie organu administracji publicznej jest rozstrzygnięciem opartym na obowiązujących przepisach oraz stwierdzonym na podstawie rzetelnych dowodów - stanie faktycznym zaistniałym $w$ danej sprawie, który odpowiada stanowi faktycznemu określonemu w przepisach prawa mających zastosowanie w sprawie, nosi wszelkie cechy rozstrzygnięcia dowolnego nieopartego na przepisach prawa. Takie uzasadnienie decyzji jest w sposób oczywisty sprzeczne $\mathrm{z}$ określoną $\mathrm{w}$ art. $8 \mathrm{KPA}$ zasadą pogłębiania zaufania obywateli do organów państwa (zob. wyr. WSA w Warszawie z 7.11.2006 r., III SA/WA 2015/06, Legalis; wyr. WSA w Warszawie z 9.5.2007 r., V SA/WA 320/07, Legalis; wyr. WSA w Warszawie z 25.5.2007 r., V SA/WA 418/07, Legalis)". Wynika z tego wniosek, iż uznaniowy charakter decyzji nie zwalnia organu administracji publicznej od obowiązku przeprowadzenia prawidłowego postępowania administracyjnego.

Stanowisko doktryny, jest potwierdzone także przez judykaturę. Naczelny Sąd Administracyjny w wyroku ${ }^{23} \mathrm{z}$ dnia 21 lutego 2013 r. odniósł się także do kryterium "ważnego interesu zainteresowanego". W opinii NSA art. 41a ust. 1 ustawy o u.s.r. wskazuje, iż decyzja Prezesa KRUS ma charakter uznaniowy. Jest to równoznaczne z tym, że organ ten przy ustalonym stanie faktycznym ma możliwość wyboru rozstrzygnięcia. Należy jednak podkreślić, że wybór taki nie oznacza dowolności, ponieważ musi wynikać z wszechstronnego oraz dogłębnego rozważenia wszystkich okoliczności faktycznych sprawy, w szczególności tych podnoszonych przez stronę. Tak więc, orzekając w konkretnej sprawie organ może, a nie musi umorzyć należności, oceniając istnienie lub nieistnienie tego kryterium, a także możliwości płatnicze wnioskodawcy oraz stan finansów funduszów emerytalnorentowego i składkowego, a w wyniku dokonanej przez siebie oceny wybiera konsekwencje prawne tych ustaleń.

${ }^{23}$ Sygn. akt II GSK 2227/11, Legalis 667079. 
Organ w sprawach o umorzenie należności ocenia aktualną, na datę podejmowania rozstrzygnięcia, sytuację życiową, w tym majątkową, wnioskodawcy. Spekulacje organu dotyczące ewentualnego zatrudnienia zobowiązanego, w kontekście możliwości uzyskania dochodu i spłaty zaległości, nie mogą mieć wpływu na ocenę aktualnej sytuacji materialnej zobowiązanego ${ }^{24}$. Założenie istnienia hipotetycznych dochodów przez organ i ocena możliwości płatniczych zobowiązanego przez ich pryzmat spowodowałoby przekroczenie granic uznania administracyjnego przez organ. Ze względu na uznaniowy charakter decyzji umorzeniowych, to na wnioskodawcy spoczywa obowiązek wykazania, że zapłata tych należności rzeczywiście może zagrozić jego egzystencji25.

\section{Treść decyzji uznaniowej w przedmiocie umorzenia odsetek od należności.}

W opinii Wojewódzkiego Sądu Administracyjnego w Warszawie wyrażonej w wyroku ${ }^{26} \mathrm{z}$ dnia 12 grudnia 2006 r., obowiązkiem organu rozstrzygającego sprawę (w ramach motywowania podjętej decyzji) jest ustosunkowanie się do wszystkich argumentów podnoszonych przez stronę $\mathrm{w}$ trakcie toczącego się postępowania. Urzeczywistnienie tego powinno znaleźć się w uzasadnieniu decyzji.

Brak odniesienia się przez organ rozstrzygający sprawę do podnoszonych zarzutów stanowi naruszenie prawa procesowego w stopniu mogącym mieć wpływ na wynik sprawy, co z kolei skutkuje uchyleniem zaskarżonej decyzji.

\footnotetext{
24 Wyrok Wojewódzkiego Sądu Administracyjnego siedziba w Kielcach z dnia 18 sierpnia 2011 r., sygn. akt I SA/Ke 347/11, Legalis 374887.

${ }^{25}$ Wyrok Wojewódzkiego Sądu Administracyjnego siedziba w Bydgoszczy z dnia 26 stycznia 2010 r., I SA/Bd 948/09, Legalis 374910.

26 Wyrok Wojewódzkiego Sądu Administracyjnego siedziba w Warszawie z dnia 12 grudnia 2006 r., sygn. akt III SA/Wa 2616/06, Legalis 91465.
} 
Fakultatywny charakter przepisu art. 41 a ust. 1 ustawy o ubezpieczeniu społecznym rolników nie stanowi usprawiedliwienia dla braku ustosunkowania się przez organ administracji do zarzutów podnoszonych przez stronę postępowania.

\section{Możliwość złożenia ponownego wniosku o umorzenie należności wobec KRUS ${ }^{27}$}

Podstawę do kolejnego wystąpienia z ponownym wnioskiem o umorzenie należności wobec KRUS może stanowić zawsze każda zmiana okoliczności faktycznych, w szczególności sytuacji majątkowej, zdrowotnej lub też rodzinnej osoby zobowiązanej.

Jak wskazał WSA w Rzeszowie w wyroku z dnia 2 grudnia 2010 r., odmowa ich umorzenia nie stwarza sytuacji powagi rzeczy osądzonej i zobowiązany do uiszczenia zaległości może występować o jej umorzenie tak długo, jak długo zaległość ta istnieje tym bardziej, jeśli jego sytuacja ulegnie pogorszeniu.

Wprawdzie pogląd ten wypowiedziano w oparciu o przepisy ustawy - Ordynacja podatkowa, to jednak według opinii WSA w Rzeszowie jest on w pełni aktualny także na gruncie ustawy o ubezpieczeniu społecznym rolników.

\section{Analiza liczby udzielonych ulg $w$ formie ratalnej spła- ty zadłużenia w 2016 r.}

Celem wyczerpania zagadnienia przedmiotowego artykułu, należy odnieść się także do praktyki i rzeczywiście udzielonych ulg w zakresie ubezpieczeń społecznych. Tabela zamieszczona poniżej

\footnotetext{
27 Wyrok Wojewódzkiego Sądu Administracyjnego siedziba w Rzeszowie z dnia 2 grudnia 2010 r., sygn. akt I SA/Rz 695/10, Legalis 374899.
} 
przedstawia zestawienie liczb zawartych układów ratalnych w 2016 r. w stosunku do liczby pracujących w rolnictwie w województwach, według stanu z dnia 31 grudnia 2015 r. Na podstawie danych Biura Ubezpieczeń Centrali KRUS można zauważyć, iż łącznie w 2016 r. zostało zawartych 29733 układów ratalnych.

Najwyższą liczbę zawartych układów ratalnych w roku 2016 (6502) wraz z najwyższą liczbą pracujących w rolnictwie (305 778) zanotowano w województwie lubelskim. Najniższą liczbę układów ratalnych zaobserwowano w województwie lubuskim (182), tam także odnotowano najniższą liczbę pracujących w rolnictwie pod koniec 2015 r. (33 233).

Na podstawie przedstawionych danych należy wysunąć wniosek, że co do zasady liczba zawieranych układów ratalnych jest, w zależności od województwa, proporcjonalna w stosunku do liczby osób, które trudnią się pracą w rolnictwie.

\begin{tabular}{|r|c|c|c|}
\hline L.p. & Oddział Regionalny & $\begin{array}{c}\text { Liczba } \\
\text { zawartych } \\
\text { układów } \\
\text { ratalnych } \\
\text { w 2016 r. } \\
28\end{array}$ & $\begin{array}{c}\text { Liczba pracujących w rolnictwie } \\
\text { według województw w XII 2015 r. }{ }^{29}\end{array}$ \\
\hline 1 & 2 & 3 & 4 \\
\hline 1 & BIAŁYSTOK (woj. podlaskie) & 1764 & 124428 \\
\hline 2 & $\begin{array}{c}\text { BYDGOSZCZ (woj. kujawsko- } \\
\text { pomorskie) }\end{array}$ & 1539 & 105314 \\
\hline 3 & $\begin{array}{c}\text { CZĘSTOCHOWA (woj. ślą- } \\
\text { skie) }\end{array}$ & 534 & 99343 \\
\hline 4 & GDAŃSK (woj. pomorskie) & 436 & 62178 \\
\hline
\end{tabular}

\begin{tabular}{l}
$28 \quad$ Biuro $\quad$ Ubezpieczeń $\quad$ CKRUS, strona \\
http://www.krus.gov.pl/fileadmin/moje_dokumenty/dokumenty/bip/wykaz_spraw \\
\hline$L$ \\
ubezpieczenia/dane_za_2016/Dane_UB_2016_ulg_rat_zal_1.pdf.pdf, dostęp:
\end{tabular} kwietnia $2017 \mathrm{r}$.

29 Rocznik Statystyczny Rolnictwa 2016, strona www: http://stat.gov.pl/obszarytematyczne/roczniki-statystyczne/roczniki-statystyczne/rocznik-statystycznyrolnictwa-2016,6,10.html, dostęp: 11 kwietnia 2017 r. 


\begin{tabular}{|c|c|c|c|}
\hline 5 & $\begin{array}{c}\text { KIELCE (woj. świętokrzy- } \\
\text { skie) }\end{array}$ & 2891 & 148040 \\
\hline 6 & $\begin{array}{l}\text { KOSZALIN (woj. zachodnio- } \\
\text { pomorskie) }\end{array}$ & 522 & 44616 \\
\hline 7 & KRAKÓW (woj. małopolskie) & 1867 & 270722 \\
\hline 8 & LUBLIN (woj. lubelskie) & 6502 & 305778 \\
\hline 9 & ŁÓDŹ (woj. łódzkie) & 2507 & 177638 \\
\hline 10 & $\begin{array}{c}\text { OLSZTYN (woj. warmińsko- } \\
\text { mazurskie) }\end{array}$ & 1050 & 65420 \\
\hline 11 & OPOLE (woj. opolskie) & 325 & 48869 \\
\hline 12 & $\begin{array}{c}\text { POZNAŃ (woj. wielkopol- } \\
\text { skie) }\end{array}$ & 2230 & 209160 \\
\hline 13 & $\begin{array}{l}\text { RZESZÓW (woj. podkarpac- } \\
\text { kie) }\end{array}$ & 1858 & 255827 \\
\hline 14 & $\begin{array}{l}\text { WARSZAWA (woj. mazo- } \\
\text { wieckie) }\end{array}$ & 4871 & 300048 \\
\hline 15 & $\begin{array}{l}\text { WROCŁAW (woj. dolnoślą- } \\
\text { skie) }\end{array}$ & 655 & 84304 \\
\hline 16 & $\begin{array}{l}\text { ZIELONA GÓRA (woj. lubu- } \\
\text { skie) }\end{array}$ & 182 & 33233 \\
\hline & RAZEM & 29733 & 2334922 \\
\hline
\end{tabular}

$\mathrm{Na}$ poniższym wykresie została przedstawiona liczba wydanych decyzji, zaświadczeń i udzielonych ulg w formie ratalnej spłaty zadłużenia według stanu z 31 grudnia 2015 r. Liczba zawartych układów ratalnych procentowo wynosi $2 \%$ całości zestawienia, co w rzeczywistości odpowiada 31759 układom ratalnym. Liczba ta nie wydaje się niska chociażby na tle 155 585, tj. 13 \% wszystkich decyzji o podleganiu ubezpieczeniu społecznemu rolników wydanych w roku 2015. 


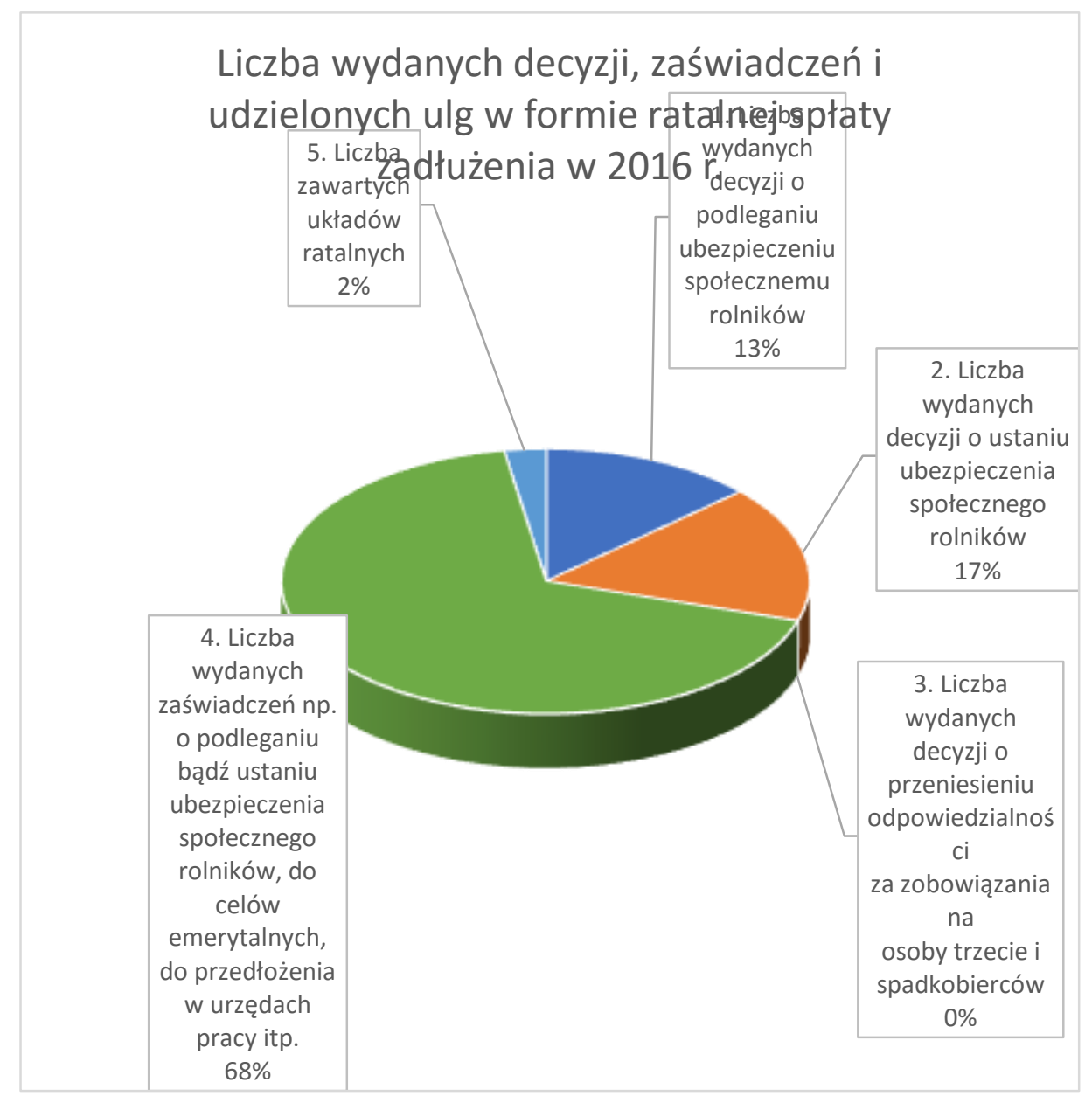

30Źródło: Dane Biura Ubezpieczeń Centrali KRUS za 2015 r.

30Dane Biura Ubezpieczeń Centrali KRUS za 2015, http://www.krus.gov.pl/fileadmin/moje_dokumenty/dokumenty/bip/wykaz_spraw /ubezpieczenia/dane_za_2015/UB_BIP_dane_2015_zal3.pdf 


\section{0pis wybranych czynników ekskulpujących odpowie- dzialność za nieterminową lub w kwocie niższej od wymaganej zapłatę składek na ubezpieczenie spo- łeczne $^{31}$}

Odpowiedzialność za naruszenie dyscypliny finansów publicznych wyrażona została w art. 19 ustawy z dnia 17 grudnia 2004 r. o odpowiedzialności za naruszenie dyscypliny finansów publicznych ${ }^{32}$. Przepis ten zakłada, że odpowiedzialność taką ponosi osoba, która popełniła czyn naruszający dyscyplinę finansów publicznych określony przez ustawę obowiązującą $\mathrm{w}$ czasie jego popełnienia, a także której można przypisać winę w czasie popełnienia naruszenia.

Jeśli w danym przypadku, osoba obwiniona nie miała innej możliwości zachowania się, wówczas mimo obiektywnego stwierdzenia popełnienia czynu zabronionego, nie będzie można przypisać tej osobie winy. Jako jedną z okoliczności ekskulpujących odpowiedzialność (wyłączających ponoszenie tej odpowiedzialności) za naruszenie dyscypliny finansów publicznych, o którym mowa w art. 14 pkt 1 u.o.n.d.f.p., należy wskazać na wyrażoną w art. 23 u.o.n.d.f.p usprawiedliwioną nieświadomość naruszenia dyscypliny finansów publicznych 33 .

Ustawodawca podkreśla również, że nie dochodzi się odpowiedzialności za naruszenie dyscypliny finansów publicznych

\footnotetext{
31 W. Bożek, Okoliczności ekskulpujące odpowiedzialność za nieterminową lub w kwocie niższej od wymaganej zapłatę składek na ubezpieczenie społeczne, Prawo Budżetowe Państwa i Samorządu, 2(2)/2014, ISSN 2300 - 9853, s. 103-107.

32 Ustawa z dnia 17 grudnia 2004 r. o odpowiedzialności za naruszenie dyscypliny finansów publicznych, Dz.U. $2005 \mathrm{nr} 14$ poz. 114, dalej: u.o.n.d.f.p.

33 W. Bożek, Okoliczności ekskulpujące odpowiedzialność za nieterminową lub w kwocie niższej od wymaganej zapłatę składek na ubezpieczenie społeczne, Prawo Budżetowe Państwa i Samorządu, 2(2)/2014, ISSN 2300 - 9853, s. 103-107.
} 
w przypadku działania lub zaniechania podjętego wyłącznie w celu ograniczenia skutków zdarzenia losowego, o czym stanowi art. 27 ust. 1 u.o.n.d.f.p. Okolicznością, która może mieć wpływ na wynik postępowania w sprawie o czyn z art. 14 pkt 1 u.o.n.d.f.p., jest również znikomy stopień szkodliwości czynu dla finansów publicznych, przy ocenie którego uwzględnia się m.in. wagę naruszonych obowiązków, sposób i okoliczności naruszenia tych obowiązków oraz ich skutki.

\section{Postulaty de lege ferenda}

Odnosząc się do potencjalnych zmian w terminologii związanych z tworzeniem prawa, należy zwrócić uwagę na zagadnienie ułatwień w opłacaniu składek. Poprzez to sformułowanie należy rozumieć wszystkie rozwiązania, które w rzeczywisty sposób pomagają płatnikom składek w trudnych dla nich sytuacjach finansowych związanych z koniecznością zapłaty składek na ubezpieczenia społeczne ${ }^{34}$.

J. Wantoch-Rekowski zaproponował modyfikację terminu I. Jędrasik-Jankowskiej: „mechanizmy ułatwiające płatnikowi zapłatę składki” przez zastąpienie nieco krótszym - „ułatwienia w opłacaniu składek"35.

Terminologia ta w pewien sposób nawiązuje do podatkowego pojęcia „ulgi w spłacie podatku”, jednak nie posługuje się wyrazem „ulga”, dzięki czemu nie ma zastrzeżeń, że jego zakres nie jest tożsamy $\mathrm{z}$ ulgami wymienionymi $\mathrm{w}$ art. 29 ustawy systemowej. Zmiana taka pozwoliłaby na inne brzmienie tego terminu oraz rozszerzenie jego znaczenia.

\footnotetext{
34 J. Wantoch - Rekowski, Ułatwienia w opłacaniu składek na ubezpieczenia społeczne - zagadnienia terminologiczne, 3(2)/2014, ISSN 2300 - 9853, s. 40-41.

35 J. Wantoch - Rekowski, Ułatwienia w opłacaniu składek na ubezpieczenia społeczne - zagadnienia terminologiczne, 3(2)/2014, ISSN 2300 - 9853, s. 40-41.
} 


\section{Podsumowanie}

Jak wynika z artykułu, mimo podlegania ubezpieczeniu społecznemu rolników i obligatoryjności opłacania przez rolników miesięcznych składek, istnieją możliwości wynikające z ustawy o systemie ubezpieczeń rolników, dzięki którym w określonych przypadkach można skorzystać z rozkładania na raty i umarzania należności.

Orzecznictwo i doktryna w przedmiotowej kwestii zdają się być spójne, przykładowo odnośnie kwestii charakteru decyzji w sprawie umarzania należności z tytułu składek, które są wydawane w ramach tzw. uznania administracyjnego i związanych z tym konsekwencji.

Rozwiązanie to jest bardzo korzystne dla rolników. Uznanie za ważny interes w umorzeniu składek ze względu na trudną sytuację ubezpieczonego, gdy pomiędzy obowiązkiem zapłaty należności i jego sytuacją materialną istnieje związek tego rodzaju, że wykonanie obowiązku zapłaty składek mogłoby spowodować niemożność zaspokojenia przez zobowiązanego i jego bliskich podstawnych potrzeb życiowych stanowi racjonalne rozwiązanie ustawodawcy. Przewidziane okoliczności ekskulpujące odpowiedzialność za nieterminową lub w kwocie niższej od wymaganej zapłatę składek na ubezpieczenie społeczne ukazuje, kiedy w danym przypadku ponoszenie odpowiedzialności może być wyłączone. $\mathrm{W}$ odniesieniu do liczb, na podstawie danych udostępnionych przez KRUS oraz GUS można wysunąć wniosek, iż instytucje rozkładania na raty i umarzania należności z tytułu składek na ubezpieczenie społeczne rolników są wykorzystywane w praktyce. 


\section{Bibliografia:}

1. A. Jonik, Umorzenie należności z tytułu składek na ubezpieczenie społeczne rolników w świetle kodeksu postępowania administracyjnego, „Ubezpieczenia w Rolnictwie” 2007, nr 30.

2. J. Wantoch - Rekowski, Ułatwienia w opłacaniu składek na ubezpieczenia społeczne - zagadnienia terminologiczne, 3(2)/2014, ISSN 2300 - 9853, DOI: http://dx.doi.org/10.12775/PBPS.2014.028.

3. Kodeks postępowania administracyjnego. Komentarz, red. prof. zw. dr hab. Roman Hauser, red. prof. zw. dr hab. Marek Wierzbowski, wyd. 3, C.H.BECK, Warszawa 2017.

4. M. Rotkiewicz, Praca $w$ gospodarstwie rolnym $w$ stażu pracy, wyjaśnienie praktyczne, 5 lipca 2016 r., Legalis.

5. W. Bożek, Okoliczności ekskulpujq̨ce odpowiedzialność za nieterminowq lub w kwocie niższej od wymaganej zapłatę składek na ubezpieczenie społeczne, Prawo Budżetowe Państwa i Samorządu, 2(2)/2014, ISSN 2300 9853, DOI: http://dx.doi.org/10.12775/PBPS.2014.019.

6. Z. Ofiarski, Przesłanki pozytywne umorzenia należności z tytułu składek na ubezpieczenie społeczne, Prawo Budżetowe Państwa i Samorządu, 2(2)/2014, ISSN $2300 \quad$ - 9853, DOI: http://dx.doi.org/10.12775/PBPS.2014.014. 